\title{
Edelfosine protects precultured heart fragments against the invasion of malignant cells through altered sialylation
}

\author{
S. VAN SLAMBROUCK ${ }^{1 *}$, W.F.A. STEELANT ${ }^{1,4^{*}}$, M. LOPEZ ${ }^{2}$, M.A. RECCHI ${ }^{2}$, Y. BOILLY-MARER ${ }^{2}$, \\ E.A. BRUYNEEL ${ }^{3}$, P. DELANNOY ${ }^{2}$, A. VERBERT ${ }^{2}$, E.G. VAN DEN EECKHOUT ${ }^{4}$ and D. DEFORCE ${ }^{4}$
}

\author{
${ }^{1}$ Department of Chemistry, Laboratory of Biochemical and Biomedical Research, New Mexico Tech, USA; ${ }^{2}$ Laboratoire de \\ Chimie Biologique (UMR no. 8576 du Centre National de la Recherche Scientifique), Université des Sciences et \\ Technologies de Lille, Villeneuve d'Ascq, France; ${ }^{3}$ Laboratory of Experimental Cancerology, Department of \\ Radiotherapy and Nuclear Medicine, University Hospital; ${ }^{4}$ Laboratory for Pharmaceutical \\ Biotechnology, University of Ghent, Harelbekestraat 72, B-9000 Ghent, Belgium
}

Received July 24, 2006; Accepted October 6, 2006

\begin{abstract}
O-octadecyl-2- $O$-methylglycero-3-phosphocholine (ET-18-OMe)-treated precultured heart fragments (PHF) are resistant to the invasion of malignant cells. Previous studies have demonstrated that this effect is due to the alterations of the N-linked glycoproteins in PHF after 48-h ET-18-OMe treatment. Moreover, the observed effect was still present seven days after ET-18-OMe was omitted. The present study reveals that $\sim 13.4 \%$ of the administered ET-18OMe was taken up by PHF and about $75 \%$ of the initial uptake was still present after ET-18-OMe was removed. In addition, we found significant changes in the sialic acid content and sialyltransferase activities in both conditions. Overall, these results clearly demonstrate that the uptake and retention of ET-18-OMe are responsible for the resistance to the invasion of malignant cells due to the altered sialylation of the cell surface glycoproteins in PHF.
\end{abstract}

\section{Introduction}

The embryonic precultured chick heart (PHF) invasion assay is used to study the anti-invasive potential of various drugs

Correspondence to: Professor Wim F.A. Steelant, Department of Chemistry, Laboratory of Biochemical and Biomedical Research, New Mexico Tech, 801 Leroy Place, Socorro, NM 87801, USA

E-mail: steelant@nmt.edu

${ }^{*}$ Contributed equally

Abbreviations: ET-18-OMe, 1-O-octadecyl-2-O-methylglycero-3phosphocholine; PHF, precultured heart fragments; HePC, hexadecylphosphocholine; PBS, phosphate buffered saline; EMEM, Eagle's minimum essential medium, SPE, solid-phase extraction; cGC, capillary gas chromatography; DPM, disintegrations per min

Key words: 1-O-octadecyl-2-O-methylglycero-3-phosphocholine, precultured heart fragments, sialylation, invasion and their underlying mechanisms of action in three dimensional cultures (1-3). The alkyllysophospholipid, 1-O-octadecyl-2$O$-methylglycero-3-phosphocholine (ET-18-OMe) (Fig. 1) is a synthetic analog of 2-lysophosphatidylcholine (4) and has been shown to inhibit the invasion of malignant cells into PHF in vitro. Previous studies have indicated that the pretreatment of PHF with $10 \mu \mathrm{g} / \mathrm{ml}(76 \mu \mathrm{M})$ ET-18-OMe for $48 \mathrm{~h}$ was sufficient to induce resistance towards invasion in host tissue by mouse BW-O-Li T-lymphoma cells, LLC-H61 Lewis lung carcinoma cells and mouse $\mathrm{MO}_{4}$ cells. Resistance was obvious when the invasiveness was assayed either immediately or after the withdrawal of ET-18-OMe from PHF, seven days prior to the confrontation with malignant cells. These observations suggest that the ET-18-OMeinduced alterations in the cardiac tissue and not the changes in the cancer cells, were responsible for the inhibition of invasion. An increase in the molecular weight of the $\mathrm{N}$ linked cell surface glycoproteins of PHF was apparent upon 48-h ET-18-OMe treatment and after the withdrawal of ET18 -OMe after seven days, prior to the confrontation with malignant cells. The latter effect and resistance towards invasion were abolished after neuraminidase treatment of PHF, suggesting a pivotal role for sialic acid (5-7).

The resistance towards invasion in PHF and the direct involvement of sialic acid after the ET-18-OMe treatment remained to be clarified. We, therefore, investigated the uptake of ET-18-OMe after 48-h treatment (uptake experiment), its retention in PHF after seven days (retention experiment) and the effect on the $\alpha 2-3$ and $\alpha 2-6$ sialylation of the cell surface glycoproteins in both conditions.

\section{Materials and methods}

Reagents. ET-18-OMe and HePC (hexadecylphosphocholine) were kindly provided by Dr T. Klenner (ASTA MEDICA, Frankfurt, Germany). Trimethylsilylbromide was obtained from Sigma (St. Louis, MO, USA). Bondelut columns containing a weak cation-exchange sorbent of the carboxylic acid type were obtained from Sopachem (Brussels, Belgium). Eagle's minimum essential medium (EMEM) with Earle's 
A<smiles>COCC(COCC[Y7](C)C)OCC[N+](C)(C)C</smiles>

Edelfosine

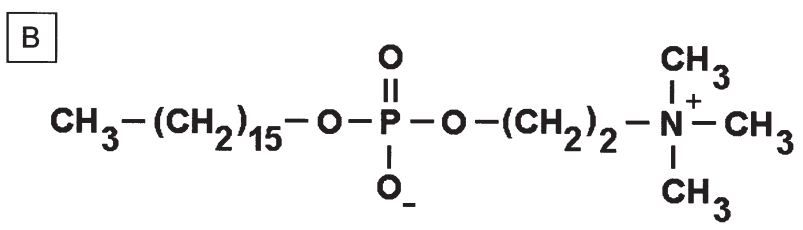

Miltefosine

Figure 1. Structures of Edelfosine, ET-18-OMe (A) and Miltefosine, HePC (B).

salts and non-essential amino acids, supplemented with $10 \%$ fetal bovine serum, was obtained from Invitrogen (Ghent, Belgium) and used as the PHF culture medium in all the experiments. The protein determination kits, Bio-Gel P-2 and P-6, were obtained from Bio-Rad (Ghent, Belgium). [Methyl- ${ }^{3} \mathrm{H}$ ] thymidine (specific activity $1.85 \mathrm{Gbq}^{\mathrm{mmol}}{ }^{-1}$ ), for the thymidine experiment, and CMP- $\left[{ }^{14} \mathrm{C}\right] \mathrm{Neu} 5 \mathrm{Ac}$ (9.61 Gbq. $\mathrm{mmol}^{-1}$ ), for the sialyltransferase activities, were purchased from ICN, France. Unlabelled CMP-Neu5Ac, fetuin and Galß1-3GalNAc $\alpha$-O-paranitrophenyl were purchased from Sigma. Sambucus Nigra agglutinin (SNA), Maackia Amurensis Agglutinin (MAA) and their digoxigenin conjugate, anti-digoxigenin Fab fragments conjugated with alkaline phosphatase, 5-bromo-4-chloro-3-indolyl-phosphate (X-phosphate), 4-nitroblue tetrazolium chloride (NBT) were from Roche (Brussels, Belgium). Other products and solvents were of analytical grade and were used without further purification.

Instrumentation. Samples derivatized with trimethylsilylbromide were injected into a Hewlett-Packard Series II gas chromatograph (8-10). A Beckman LS 3801 (CA, USA) scintillation counter was used for the thymidine incorporation and sialyltransferase activity measurements. For the protein determination, a Lambda 15 UV/VIS spectrophotometer was used from Perkin-Elmer (San Jose, CA, USA).

Standard curve. Standards of ET-18-OMe were prepared in a concentration range of $1-50 \mu \mathrm{g} / \mathrm{ml}(7.6-380 \mu \mathrm{M})$ in the culture medium. HePC $(50 \mu \mathrm{g} / \mathrm{ml})$ (Fig. 1) in the culture medium was used as an internal standard and added to each aliquot. Subsequently, the standards were subjected to a solid-phase extraction (SPE), and treated as described earlier (8).

Host tissue. Nine-day-old embryonic chick hearts were cut into $0.4 \mathrm{~mm}$ diameter fragments and cultured for $48 \mathrm{~h}$ at $37^{\circ} \mathrm{C}, 5 \% \mathrm{CO}_{2}$, before use and were referred to as PHF. A single Erlenmeyer flask on a Gyratory shaker contained the equivalent of three chick hearts.

Thymidine incorporation. The PHF were cultured in 24-well plates (50 PHF per well). After the removal of the medium, $1 \mathrm{ml}$ culture medium, containing $20 \mu \mathrm{Ci}$ of [methyl- ${ }^{3} \mathrm{H}$ ] thymidine was added and cultured for $24 \mathrm{~h}$ at $37^{\circ} \mathrm{C}, 5 \% \mathrm{CO}_{2}$. The $\mathrm{PHF}$ were subsequently rinsed with sodium phosphate buffer (pH 7.4) (PBS), treated with ice-cold 5\% trichloroacetic acid $\left(45 \mathrm{~min}, 40^{\circ} \mathrm{C}\right)$ and solubilized in $1 \mathrm{ml} 0.3 \mathrm{M} \mathrm{NaOH}(1 \mathrm{~h}$, $\left.37^{\circ} \mathrm{C}\right)$. Radioactivity was measured with a scintillation counter.

Uptake and retention measurements of ET-18-OMe. Five out of ten Erlenmeyer flasks were used to measure the uptake of ET-18-OMe into PHF. Therefore, the PHF were treated for $48 \mathrm{~h}$ with $10 \mu \mathrm{g} / \mathrm{ml}$ ET-18-OMe followed by the removal of the medium and wash steps with PBS (pH 7.6). Subsequently, the PHF were collected in $5 \mathrm{ml}$ PBS ( $\mathrm{pH} 5.2$ ), homogenized by ultrasonic waves (Biodisruptor, Analis, Ghent, Belgium) and transferred to volumetric flasks of $10 \mathrm{ml}$. SPE was carried out for PHF suspension and culture media, followed by derivatization and injection into the capillary gas chromatography (cGC) system (10). Likewise, incubating media (1 ml) were analyzed as the control. Data were collected by means of an HP Chemstation and a standard curve of ET-18-OMe with $\mathrm{HePC}$, as an internal standard, was obtained by plotting the ratios of the peak areas of ET-18-OMe vs HePC. For the retention measurements, the incubating media were removed and ET-18-OMe-free medium was added to the five remaining Erlenmeyers containing PHF, followed by further incubation for seven days. The quantitative measurements of ET-18$\mathrm{OMe}$ are as described above. For both the uptake and retention measurements a Bio-Rad cell protein determination was used in order to express the amount of ET-18-OMe per milligram protein.

Sialyltransferase assays. For the sialyltransferase activities, the PHF were washed in PBS and homogenized by ultrasonic waves in $5 \mathrm{ml}$ PBS, containing $0.25 \mathrm{M}$ sucrose. The pellets were removed, after centrifugation at 3,000 $\mathrm{x}$ g for $5 \mathrm{~min}$, while the supernatants were further centrifuged at $105,000 \mathrm{x} g$ for $1 \mathrm{~h}$. The obtained supernatants were discarded, and the microsomal fractions were solubilized in $500 \mu 1$ of $10 \mathrm{mM}$ sodium cacodylate, $\mathrm{pH} 6.5$, containing $1 \%$ Triton $\mathrm{X}-100,20 \%$ glycerol, $5 \mathrm{mM}$ dithiothreitol and $5 \mathrm{mM} \mathrm{MnCl}_{2}$, and used for the enzyme assays.

Galß1-3GalNAca-O-paranitrophenyl as substrate. The substrate Galß1-3GalNAc $\alpha-O$-paranitrophenyl was used to determine the sialyltransferase activity of Galß13GalNAca2,3-sialyltransferase [ST3(O)-I; EC 2.4.99.4], responsible for the $\alpha-2,3$ sialylation of the O-linked core 1 glycoproteins (11). Therefore, the aliquots of the PHF suspensions (50 $\mu \mathrm{l}$, corresponding to $21-72.5 \mu \mathrm{g}$ protein) were brought to a final volume of $180 \mu \mathrm{l}$ with $0.1 \mathrm{M}$ sodium cacodylate $\mathrm{pH} 6.5,0.8 \%$ Triton $\mathrm{X}-100,0.2 \mathrm{M}$ galactose (to inhibit $\beta$-galactosidases), 1 mM 2,3-dehydro-2-deoxyNeu5Ac (to inhibit neuraminidases), $53 \mu \mathrm{M} \mathrm{CMP}-\left[{ }^{14} \mathrm{C}\right]-$ Neu5Ac (0.58 Gbq.mmol ${ }^{-1} ; 5.5 \mathrm{kBq} / 180 \mu \mathrm{l}$, containing $665 \mu \mathrm{g}$ 
Galß1-3GalNAc $\alpha-O-$-paranitrophenyl. The enzymatic reactions were stopped after 2 and $4 \mathrm{~h}$, by adding one volume of ethanol (1:1). Subsequently, the samples were centrifuged at $4000 \mathrm{rpm}$, $4^{\circ} \mathrm{C}$ for $4 \mathrm{~min}$ and the supernatants were further processed for scintillation counting (12).

Asialo-fetuin as substrate. The substrate asialo-fetuin was used to determine the enzymatic activities of three enzymes: CMP-sialic acid, Galß1-4GlcNAca2-6sialyltransferase; CMP-sialic acid, Galß1-3GalNAca1-Ser sialyltransferase; and CMP-sialic acid, Galß1-3(4)GlcNAca2-3 sialyltransferase. Therefore, the aliquots of the PHF suspensions (60 $\mu 1$, corresponding to 5-30 $\mu \mathrm{g}$ protein) were brought to a final volume of $180 \mu \mathrm{l}$, with $0.1 \mathrm{M}$ sodium cacodylate $\mathrm{pH} 6.5$, $0.8 \%$ Triton $\mathrm{X}-100,0.2 \mathrm{M}$ galactose, $1 \mathrm{mM}$ 2,3-dehydro-2deoxy-Neu5Ac, $53 \mu \mathrm{M}$ CMP-[ $\left[{ }^{14} \mathrm{C}\right]-\mathrm{Neu} 5 \mathrm{Ac}\left(0.58 \mathrm{Gbq}^{\mathrm{mmol}}{ }^{-1}\right.$, $5.5 \mathrm{kBq} / 180 \mu \mathrm{l}$ ), containing $370 \mu \mathrm{g}$ asialo-fetuin (prepared by mild acid hydrolysis of the native glycoprotein). Enzymatic reactions were stopped after 1 and $3 \mathrm{~h}$, by adding $1 \mathrm{ml}$ icecold phosphotungstic acid ( $5 \%$ in $\mathrm{HCl}, 2 \mathrm{M})$. The precipitates were collected on glass fiber filters, washed extensively with $5 \%$ trichloroacetic acid, distilled water and ethanol, and further processed for scintillation counting (12).

To investigate the effect of ET-18-OMe on the surface glycopeptide profiles, the reactions were stopped after $16 \mathrm{~h}$, and the samples were brought on a Bio-Gel P-6 column using amino acetic acid (0.1 M, pH 7.2), in order to separate the sialylated products from the remaining substrate. Next, the sialylated products were collected and desalted on a Bio-Gel P-2 column equilibrated in water followed by lyophilization. The samples were evaporated under a vacuum, after $\beta$-elimination in $0.1 \mathrm{M} \mathrm{NaOH}$ containing $1 \mathrm{M} \mathrm{BH}_{4} \mathrm{Na}$ at $45^{\circ} \mathrm{C}$ for two days, and washed with methanol (13). The O-linked glycans were separated from the $\mathrm{N}$-linked glycopeptides by gel permeation on a Bio-Gel P-6, equilibrated in $0.1 \mathrm{M}$ amino acetic acid, $\mathrm{pH} 7.2$ and processed for scintillation counting (12).

Biotinylation of cell surface proteins. To investigate the sialylation of the cell surface proteins, PHF, either treated with neuraminidase $(50 \mathrm{mU} / \mathrm{ml})$ or not (14) were biotinylated, in accordance with Litvinov and Hilkens (15). Briefly, the cultures were incubated with $100 \mu \mathrm{g} / \mathrm{ml} \mathrm{N}$-hydroxydisulfosuccimidebiotin (NHS-SS-biotin, Pierce, Chemical Co., Rockford, IL, USA) for $30 \mathrm{~min}$ at $0^{\circ} \mathrm{C}$. The biotinylated proteins were recovered with avidin-agarose beads $(50 \%)$ (Pierce) and prepared for Western blotting.

Western blotting of cell surface glycoproteins. The protein PHF $(20 \mu \mathrm{g})$, after the uptake and retention of ET-18-OMe, were separated on 4-20\% gradient SDS/PAGE gels, under reducing conditions. Western blotting on nitrocellulose membranes was performed as described earlier (16). The presence of sialic acid (sialylated $\mathrm{N}$ - and O-glycan chains) linked $\alpha 2-3$ or $\alpha 2-6$ to galactose was measured through the binding of MAA conjugated with digoxigenin (MAA-dig) and SNA conjugated with digoxigenin (SNA-dig). Membranes, with or without $50 \mathrm{mU} / \mathrm{ml}$ neuraminidase from Clostridium perfringens (Sigma) (in $50 \mathrm{mM}$ citrate buffer $\mathrm{pH} 6.0,0.9 \%$ $\left.\mathrm{NaCl}, 0.1 \% \mathrm{CaCl}_{2}\right)$ at $37^{\circ} \mathrm{C}$, were incubated with anti-digoxi-

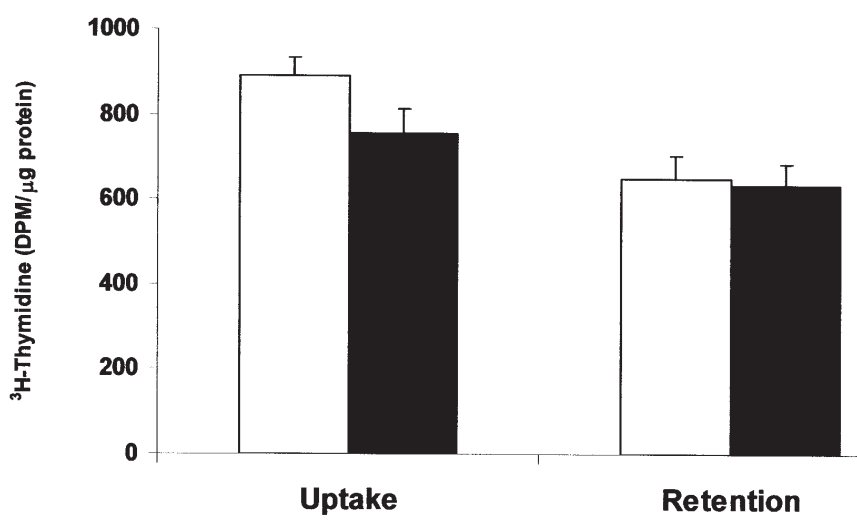

Figure 2. Effect of ET-18-OMe on ${ }^{3} \mathrm{H}$-thymidine incorporation in PHF (black columns) after 48 -h treatment (uptake experiment) or seven days after the removal of ET-18-OMe from the medium (retention experiment). The white columns represent the controls. The bars and flags indicate the mean values and standard deviations.

genin alkaline-phosphatase-labeled Fab fragments (Boehringer Mannheim) (1 $\mu \mathrm{g} / \mathrm{ml}$ TBS $)$. Labeled glycoproteins were detected by NBT/X-phosphate staining according to the Boehringer Glycan detection kit protocol with minor modifications (17).

Statistics. The student's t-test $(\mathrm{p}=0.95)$ was used for the statistical evaluation of the sialyltransferase activities. All the experiments were carried out at least three times.

\section{Results}

Effects of ET-18-OMe on proliferation of PHF. The ${ }^{3} \mathrm{H}-$ thymidine incorporation in the DNA of PHF treated with ET18 -OMe in the uptake experiments was $756.3 \pm 59 \mathrm{DPM} / \mu \mathrm{g}$ protein and $890.2 \pm 50 \mathrm{DPM} / \mu \mathrm{g}$ protein for the controls, while the ${ }^{3} \mathrm{H}$-thymidine incorporation in PHF treated according to the retention experiments was $635.4 \pm 52 \mathrm{DPM} / \mu \mathrm{g}$ protein and $650.6 \pm 56 \mathrm{DPM} / \mu \mathrm{g}$ protein for the controls (Fig. 2). These data demonstrate a decrease in the ${ }^{3} \mathrm{H}$-thymidine incorporation for the uptake experiments compared to the controls. However, this effect could not be observed for the retention experiments. Overall, the incorporation of ${ }^{3} \mathrm{H}$-thymidine in PHF was decreased in the uptake experiments compared to the retention experiments.

Levels of uptake and retention of ET-18-OMe. The uptake and retention measurements of ET-18-OMe in PHF and incubating media are shown in Fig. 3A-C. An average of $13.4 \pm 3.9 \%$ of ET-18-OMe $(20.6 \pm 1.7 \mu \mathrm{g}$ ET-18-OMe/mg protein) was taken up by PHF after 48 -h treatment (Fig. 3A-C) and $\sim 70 \%$ of the initial uptake, $8.2 \pm 3 \%(15.4 \pm 1.9 \mu \mathrm{g}$ ET-18$\mathrm{OMe} / \mathrm{mg}$ protein), was detected after seven days in the ET18-OMe-free medium (Fig. 3B-C).

The amount of ET-18-OMe, present in PHF and the incubating media at both time points, was measured and expressed as the percentage of ET-18-OMe dissolved in the culture medium. The average recovery of ET-18-OMe in PHF and the incubating media was $99.6 \pm 3.9 \%$. 




Figure 3. The levels of the uptake and retention of ET-18-OMe in PHF (A-C) and the media (A and B). The uptake measurements in PHF were after 48-h treatment (A and C) or retention, seven days after the removal of ET-18-OMe from the media (B and C). ${ }^{*}$ The results are expressed as the percentage of the amount of ET-18-OMe dissolved in the media and added to PHF $(60 \mu \mathrm{g}) ;+$, results after 48-h uptake; ++, results for incubating the media used for retention testing. The bars and flags indicate the mean values and standard deviations.

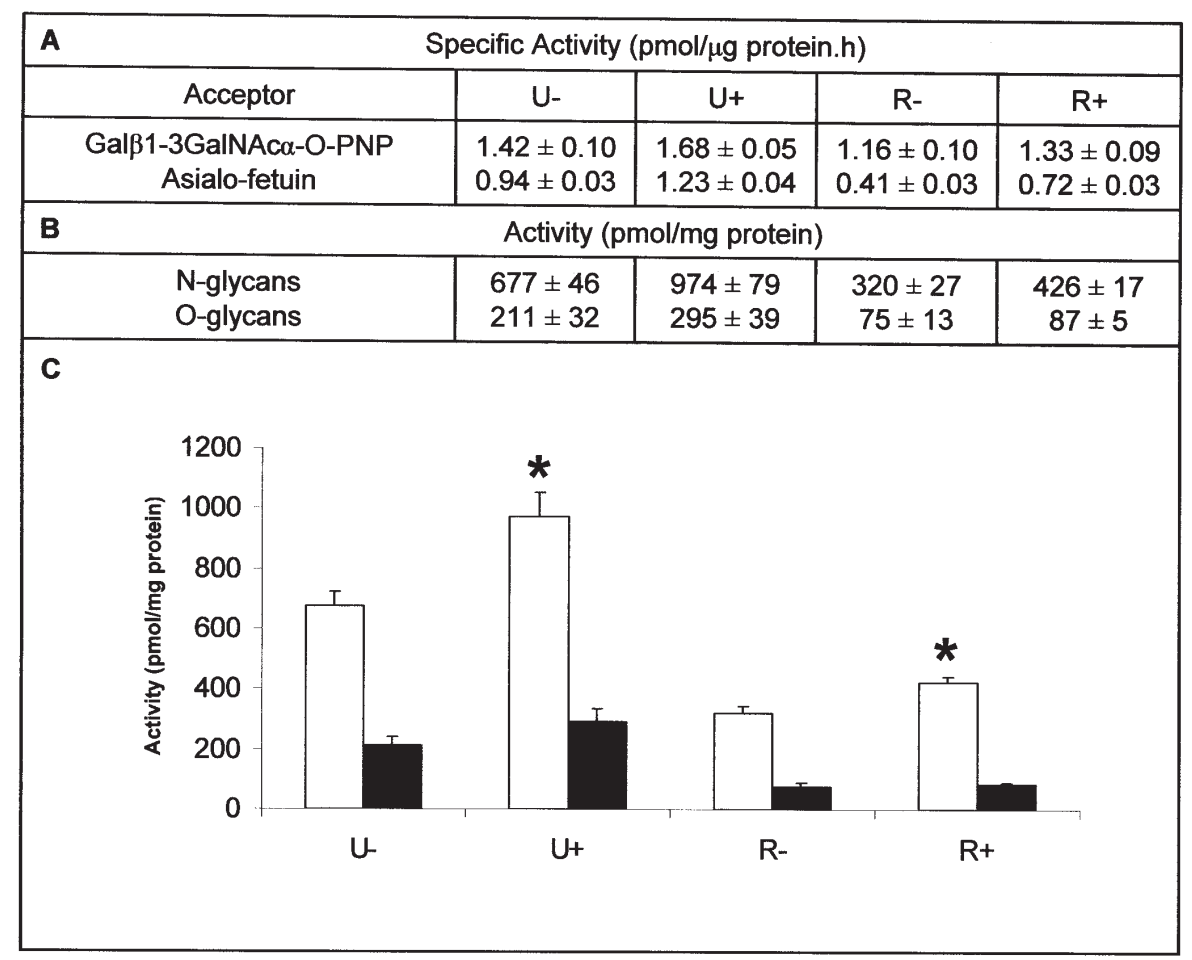

Figure 4. The sialyltransferase activity of the PHF homogenates. Incubations were performed as described in Materials and methods. Asialo-fetuin and Galß1$3 \mathrm{GalNAc} \alpha$-O-PNP were used as acceptor sides (A). Fractionation by gel-permeation of the $\left[{ }^{14} \mathrm{C}\right]$-sialylated glycans was obtained from asialo-fetuin sialylated by the PHF homogenates. The reduced oligosaccharides were separated in the N-glycans (B and C, white columns) and the O-glycans (B and C, black columns). $\mathrm{U}^{+}$, after 48-h treatment with ET-18-OMe; U-, control; $\mathrm{R}^{+}, 48$-h pretreatment with ET-18-OMe and cultured in ET-18-OMe-free medium for an additional seven days; $\mathrm{R}^{-}$, the control. The bars and flags indicate the mean values and standard deviations. The asterisks indicate the statistical difference from the control. 
Validation of the cGC method. The linearity of the cGC determination was established in a concentration range of 0 to $50 \mu \mathrm{g} / \mathrm{ml}$ ET-18-OMe in the culture medium, with $50 \mu \mathrm{g} / \mathrm{ml}$ $\mathrm{HePC}$, as an internal standard. A correlation coefficient of 0.999 was obtained with a standard deviation of 0.02 . The retention time variability of ET-18-OMe and $\mathrm{HePC}$ was $0.01 \%(n=8)$. The detection limit of the method in the culture medium was $0.5 \mu \mathrm{g} / \mathrm{ml}$. For both the uptake and retention measurements, blanks were run and no levels of ET-18-OMe could be detected.

Effect on sialyltransferase activities. The sialyltransferase activities of PHF were assayed, using two substrates: Galß13 GalNAc $\alpha-O-$ paranitrophenyl and asialo-fetuin. The enzymatic activities for both substrates in the uptake and retention experiments were significantly increased compared to the controls. In addition, higher enzymatic activities were observed in the uptake experiments (Fig. 4A).

The enzymatic activities of the sialyltransferases on the $\mathrm{N}$-glycoproteins for both the uptake and retention experiments were significantly increased as compared to the controls. In addition, the enzymatic activities of the sialyltransferases on the $\mathrm{N}$ - and O-glycoproteins were noticeably higher in the uptake experiments than in the retention experiments. No significant differences were observed in the sialyltransferase activities on the O-glycoproteins for the uptake and retention experiments compared to the controls (Fig. 4B-C).

Detection of $\alpha$ 2-3 and $\alpha 2-6$ linked sialic acid residues on cell surface glycoproteins. The PHF, after 48-h ET-18-OMe treatment, were left untreated for seven days and were then separated by SDS page (Fig. 5). Increased $\alpha 2-3$ and $\alpha 2-6$ linked sialic acid residues at the cell surface of PHF were found in the uptake and retention experiments as compared to the controls (Fig. 5A). The latter could not be observed for PHF treated with neuraminidase (Fig. 5B). No aspecific binding of the lectins SNA and MAA occurred, as evidenced by the treatment with neuraminidase (Fig. 5C).

\section{Discussion}

Cell surface glycoproteins are involved in cell-cell and cellmatrix interactions. Changes in glycosylation such as branching, sialylation, fucosylation, and the expression of Lewis $\mathrm{X}$ and sialyl Lewis $\mathrm{X}$ antigens are correlated with either the promotion or inhibition of invasion and metastasis $(18,19)$.

The PHF invasion assay is used to study the anti-invasive potential of various drugs and their underlying mechanisms of action (1-3). Previous studies have reported that ET-18OMe inhibited the invasion of a variety of cancer cells into PHF in the following experimental conditions: i) Permanent treatment with ET-18-OMe $(20,21)$, or ii) 48 -h pretreatment with ET-18-OMe prior to the confrontation with the tumor cells $(6,22)$, and iii) in a reversibility experiment, 48 -h pretreatment with ET-18-OMe and culturing in ET-18-OMe-free medium for an additional seven days, prior to the confrontation with the tumor cells (23). These observations suggest that alterations in the glycosylation of the cell surface glycoproteins of PHF, and not the changes in the cancer cells, were

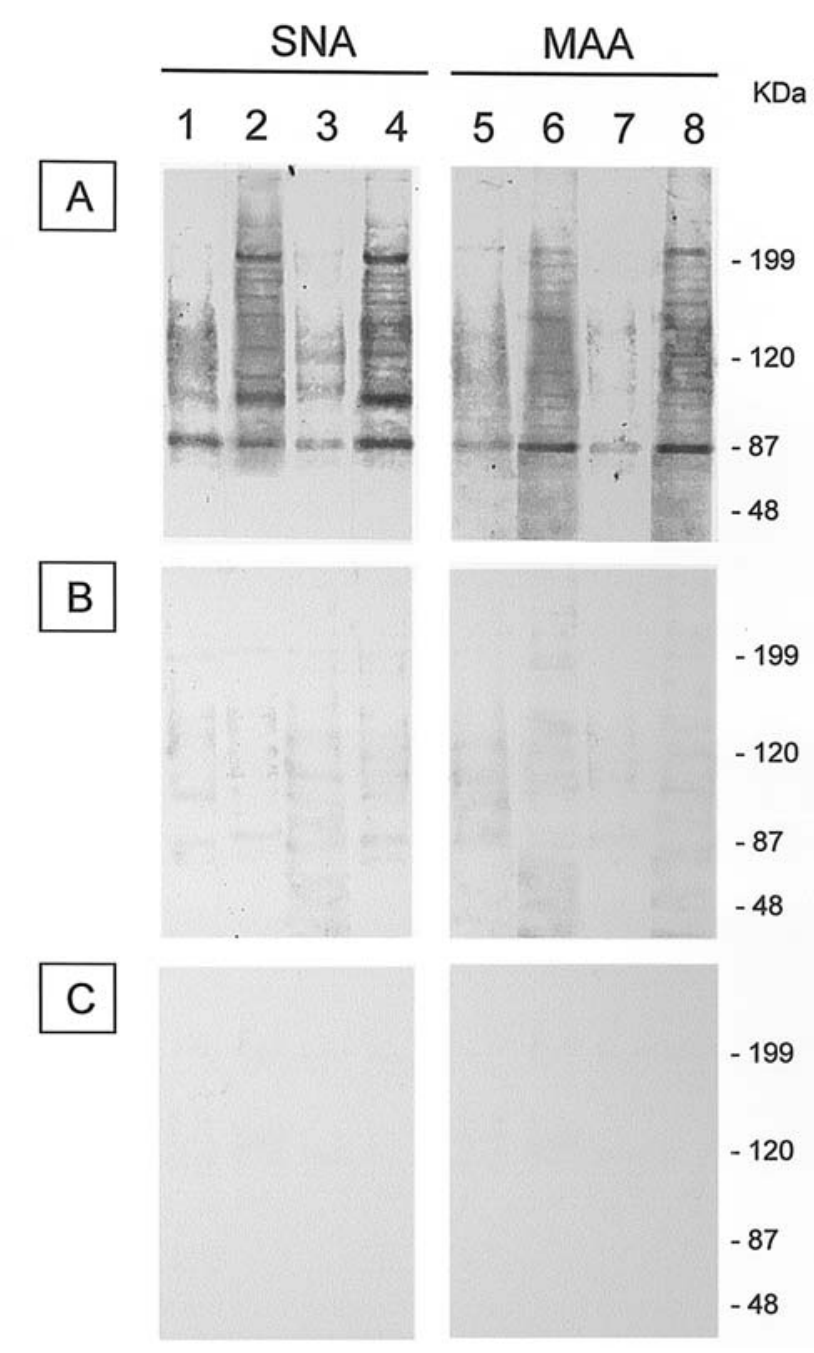

Figure 5. Western blot analysis of the cell surface glycoproteins for PHF either treated (A) with neuraminidase or not (B) or the membranes treated with neuramindase $(C)$ and stained with lectins for sialic acid as described in Materials and methods. Sialic acid ( $\alpha 2-6)$ was determined with SNA after 48-h treatment (lane 2) and seven days after the removal of ET-18-OMe from the medium (lane 4). Lanes 1 and 3 are the negative controls. Sialic acid ( $\alpha 2-3)$ was also determined with MAA after 48-h treatment (lane 6) and seven days after the removal of ET-18-OMe from the medium (lane 8). Lanes 5 and 7 are negative controls.

responsible for the inhibition of invasion. Both the alterations in the glycosylation of the cell surface glycoproteins and the resistance towards invasion were abolished after neuraminidase treatment of PHF, suggesting a pivotal role for sialic acid (5-7). Additionally, ET-18-OMe-mediated resistance towards invasion has been demonstrated in vivo. A significant decrease in tumor formation was observed in rats treated with ET-18$\mathrm{OMe}$, prior to the inoculation with mammary carcinomas, suggesting that ET-18-OMe was responsible for alterations in the host tissue (24).

Previous data have revealed a strong correlation between the cellular uptake and effect of ET-18-OMe (25-31), on cellcell adhesion and invasion in particular $(32,33)$. A possible explanation for the ET-18-OMe-induced alterations in glycosylation with resistance towards invasion could be ascribed to the uptake and retention of ET-18-OMe in PHF. The cGC method developed in our laboratory $(8,9)$ proved to be useful for the analytical measurements of not only 
alkylphospholipids in cell-monolayers (10) but also in complex tissues, such as PHF. Our data clearly show that an average of $13.4 \%$ ET-18-OMe was taken up by PHF and about $75 \%$ of the original uptake was still present after seven days in ET-18-OMe-free medium. The retention of ET-18-OMe was due to the slower proliferation rate of PHF as compared to the cells cultured in vitro, thereby diluting the incorporated ET-18-OMe. The viability of these fragments was evidenced by the thymidine incorporation, and has previously been shown in migration experiments where no significant differences were observed between the pretreated and untreated PHF (7). Additionally, ET-18-OMe has a longer half-life compared to its parent compound 2-lysophosphatidylcholine $(4,33)$ which is in line with the lack of metabolic breakdown for the duration of the assays (Fig. 3).

Our results show that ET-18-OMe induced changes in the sialic acid content and the sialyltransferase activities on the $\mathrm{N}$-glycoproteins. Both were significantly enhanced in the PHF treated with ET-18-OMe for $48 \mathrm{~h}$ or seven days after the removal of ET-18-OMe. In addition, the sialyltransferase activities were decreased in the retention experiments due to the long-time culturing in vitro and not the presence of ET18-OMe. Correspondingly, an increase in the $\alpha 2-3$ and $\alpha 2-6$ sialylation of the surface glycoproteins was apparent and could still be observed seven days after the omission of ET18-OMe.

It is still speculative as to how ET-18-OMe increased the levels of sialic acid. The ET-18-OMe-mediated increase in the sialyltransferase activities in the N-linked glycoproteins is in line with the higher levels of the $\alpha 2-3$ and $\alpha 2-6$ sialic acid moieties of PHF. These correlations are unfortunately not always straight forward. In a previous study, we showed that ET-18-OMe altered the sialyltransferase mRNA levels and enzymatic activities in MCF-7 breast cancer cells, while no changes in the peripheral sialic acid could be observed (32).

Sialic acid has been associated with invasion and metastasis $(19,35)$. Furthermore, the elevated sialylation of the surface glycoproteins is frequently observed in malignant tumors (19). Sialic acid is negatively charged and several studies describe the electrostatic repulsion between the sialic acid moieties (18,36-39). A possible explanation may be the repulsion between the sialic acid of malignant cells and the sialic acid of PHF treated with ET-18-OMe, which correlates with the resistance towards invasion.

In conclusion, we suggest that the uptake and retention of ET-18-OMe play a crucial role in the resistance towards invasion in PHF by altering the $\alpha 2-3$ and $\alpha 2-6$ sialylation of the cell surface glycoproteins in PHF.

\section{Acknowledgements}

This manuscript is in remembrance of Professor André Verbert and Professor E. Van den Eeckhout. This study was supported by the US National Institutes of Health (RR-16480) under the BRIN/INBRE program of the National Center for Research Resources, the New Mexico Tech startup funds and by 'De Vlaamse Kankerliga', Brussels, Belgium. The comments and discussions with Professor L.A. Smets (The Netherlands Cancer Institute, Amsterdam), Professor M.M.
Mareel (Laboratory of Experimental Cancerology, University of Ghent, Belgium), Dr Anne Harduin-Lepers and Isabelle Kim, Laboratoire de Chimie Biologique (UMR no. $8571 \mathrm{du}$ Centre National de la Recherche Scientifique), Université des Sciences et Technologies de Lille, Villeneuve d'Ascq, France) are gratefully acknowledged.

\section{References}

1. Mareel M, Kint J and Meyvisch C: Methods of study of the invasion of malignant $\mathrm{C} 3 \mathrm{H}$-mouse fibroblasts into embryonic chick heart in vitro. Virchows Arch Zellpathologie 30: 95-111, 1979.

2. De Corte V, Van Impe K, Bruyneel E, Boucherie C, Mareel M, Vandekerckhove $\mathrm{J}$ and Gettemans J: Increased importin-betadependent nuclear import of the actin modulating protein CapG promotes cell invasion. J Cell Sci 117: 5283-5292, 2004.

3. Stove C, Boterberg T, Van Marck V, Mareel M and Bracke M: Bowes melanoma cells secrete heregulin, which can promote aggregation and counteract invasion of human mammary cancer cells. Int J Cancer 114: 572-578, 2005.

4. Lohmeyer M and Bittman R: Antitumor ether lipids and alkylphosphocholines. Drugs of the Future 19: 1021-1037, 1994.

5. Bolscher JGM, Schallier DCC, Smets LA, van Rooy H, Collard JH, Bruyneel EA and Mareel MMK: Effect of cancerrelated and drug-induced alterations in surface carbohydrates on the invasive capacity of mouse and rat cells. Cancer Res 46: 4080-4086, 1986.

6. Bolscher JGM, Schallier DCC, van Rooy H, Storme GA and Smets LA: Modification of cell surface carbohydrates and invasive behavior by an alkyl lysophospholipid. Cancer Res 48 : 977-982, 1988.

7. Schallier DCC, Bruyneel EA, Storme GA and Mareel MM: Role of the host tissue in the anti-invasive activity of the alkyllysophospholipid, ET-18-OMe, in vitro. Clin Exp Metastasis 6: 579-591, 1991.

8. Coene J, Herdewijn P, Van den Eeckhout E, Van den Bossche W and Sandra P: Capillary GC analysis of alkyl lysophospholipids after derivatization with trimethylsilylbromide. J High Res Chromatography 14: 699-701, 1991.

9. Coene J, Van den Eeckhout E and Herdewijn P: Gas chromatographic determination of alkyl lysophospholipids after solidphase extraction from cell culture media. J Chromatogr B Biomed Appl 612: 21-26, 1993.

10. Steelant WFA, Bruyneel EA, Mareel MM and Van den Eeckhout EG: Capillary gas chromatography of hexadecylphosphocholine in Caco-2T cells and cell culture media. Anal Biochem 227: 246-250, 1995.

11. Delannoy P, Pelczar H, Vandamme V and Verbert A: Sialyltransferase activity in FR3T3 cells transformed with ras oncogene: decreased CMP-Neu5Ac:Galß1-3GalNAc $\alpha-2,3-$ sialyltransferase. Glycoconj J 10: 91-98, 1993.

12. Vandamme V, Cazlaris H, Le Marer N, Laudet V, Lagrou C, Verbert A and Delannoy Ph: Comparison of sialyl- and $\alpha-1,3-$ galactosyltransferase activity in NIH3T3 cells transformed with ras oncogene: increased $\beta$-galactoside $\alpha-2,6$-sialyltransferase. Biochimie 74: 89-100, 1992 .

13. Vandamme V, Pierce A, Verbert A and Delannoy P: Transcriptional induction of $\beta$-galactosidase $\alpha$-2,6-sialyltransferase in rat fibroblast by dexamethasone. Eur J Biochem 211: 135-140, 1993.

14. Deman JJ, Bruyneel EA and Mareel MM: A study on the mechanism of intercellular adhesion. Effects of neuraminidase, calcium, and trypsin on the aggregation of suspended HeLa cells. J Cell Biol 60: 641-652, 1974.

15. Litvinov SV and Hilkens J: The epithelial sialomucin, episialin, is sialylated during recycling. J Biol Chem 5: 21364-21371, 1993.

16. Glass WF 2nd, Briggs RC and Hnilica LS: Use of lectins for detection of electrophoretically separated glycoproteins transferred onto nitrocellulose sheets. Anal Biochem 115: 219$224,1981$.

17. Strub JM, Goumon Y, Lugardon K, Capon C, Lopez M, Moniatte M, Van Dorsselaer A, Aunis D and Metz-Boutigue MA: Antibacterial activity of glycosylated and phosphorylated chromogranin A-derived peptide 173-194 from bovine adrenal medullary chromaffin granules. J Biol Chem 271: 28533-28540, 1996. 
18. Laidler P and Litiyska A: Tumor cell N-glycans in metastasis. Acta Biochim Pol 44: 343-357, 1997.

19. Hakomori S: Tumor malignancy defined by aberrant glycosylation and sphingo(glyco)lipid metabolism. Cancer Res 56: 5309-5318, 1996.

20. Storme GA, Berdel WE, Van Blitterswijk WJ, Bruyneel EA, De Bruyne GK and Mareel MM: Anti-invasive effect of racemic 1-O-octadecyl-2-O-methylglycero-3-phosphocholine on $\mathrm{MO}_{4}$ mouse fibrosarcoma cells in vitro. Cancer Res 45: 351-357, 1985.

21. Storme GA, Bruyneel EA, Schallier DC, Bolscher JG, Berdel WE and Mareel MM: Effect of lipid dertivatives on invasion in vitro and on surface glycoproteins of three rodent cell types. Lipids 22: 847-850, 1987.

22. Schallier DCC, Bolscher JGM and Smets LA: Alterations in cell surface carbohydrates affecting invasion in vitro. Lectins and Glycoconjugates in Oncology. Gabius HJ and Nagel GA (eds). Springer-Verlag, Berlin, pp87-96, 1988.

23. Bruyneel EA, Schallier DC, Bolscher JG, Storme GA, De Mets M and Mareel MM: Effects of racemic 1-O-octadecyl-2-Omethylglycero-3-phosphocholine $\left(\mathrm{ET}-18-\mathrm{OCH}_{3}\right)$ on invasion in vitro and on $\mathrm{N}$-linked surface glycosylation. Pharmacological Effects of Lipids III. Kabara JJ and Champaign IL (eds). JAOCS, pp301-310, 1989.

24. Berger MR, Munder PG, Schmahl D and Westphal O: Influence of the alkyl-lysophospholipid ET-18-OCH3 on methylnitrosourea-induced rat mammary carcinomas. Oncology 41: $109-113,1984$

25. Mollinedo F, Fernandez-Luna JL, Gajate C, Martin-Matrin B, Benito A, Martinez-Dalmau R and Modolell M: Selective induction of apoptosis in cancer cells by the ether lipid ET-18OCH3 (Edelfosine): molecular structure requirements, cellular uptake, and protection by $\mathrm{Bcl}-2$ and $\mathrm{Bcl}-\mathrm{X}(\mathrm{L})$. Cancer Res 57: 1320-1328, 1997

26. Gajate C, Fonteriz RI, Cabaner C, Alvarez-Noves G, AlvarezRodriguez Y, Modolell M and Mollinedo F: Intracellular triggering of Fas, independently of FasL, as a new mechanism of antitumor ether lipid-induced apoptosis. Int J Cancer 85: 674-682, 2000.

27. Storch J and Munder PG: Increased membrane permeability for an antitumoral alkyl lysophospholipid in sensitive tumor cells. Lipids 22: 813-819, 1987.

28. Heesbeen EC, Verdonck LF, Haagmans M, van Heugten HG, Staal GE and Rijksen G: Adsorption and uptake of the alkyllysophospholipid ET-18-OCH3 by HL-60 cells during induction of differentiation by dimethylsulfoxide. Leuk Res 17: 143-148, 1993.
29. Fujiwara K, Daniel LW, Modest EJ and Wallen CA: Relationship of cell survival, drug dose, and drug uptake after 1-Ooctadecyl-2-O-methyl-rac-glycero-3-phosphocholine treatment. Cancer Chemother Pharmacol 34: 472-476, 1994.

30. Zoeller RA, Layne MD and Modest EJ: Animal cell mutants unable to take up biologically active glycerophospholipids. J Lipid Res 36: 1866-1875, 1995.

31. Cabaner C, Gajate C, Macho A, Munoz E, Modolell M and Mollinedo F: Induction of apoptosis in human mitogenactivated peripheral blood T-lymphocytes by the etherphospholipid ET-18-OCH3: involvement of the Fas receptor/ ligand system. Br J Pharmacol 127: 813-825, 1999.

32. Steelant WFA, Recchi MA, Noe VT, Boilly-Marer Y, Bruyneel EA, Verbert A, Mareel MM and Delannoy Ph: Sialylation of E-cadherin does not change the spontaneous or ET-18-OMe-mediated aggregation of MCF-7 human breast cancer cells. Clin Exp Metastasis 17: 245-253, 1999.

33. Steelant WF, Goeman JL, Philippe J, Oomen LC, Hilkens J, Krzewinski-Recchi MA, Huet G, Van der Eycken J, Delannoy P, Bruyneel EA and Mareel MM: Alkyl-lysophospholipid 1-Ooctadecyl-2-O-methyl-glycerophosphocholine induces invasion through episialin-mediated neutralization of E-cadherin in human mammary MCF-7 cells in vitro. Int J Cancer 15: 527-536, 2001.

34. Gajate $\mathrm{C}$ and Mollinedo F: Biological activities, mechanisms of actions and biomedical prospects of the antitumor ether phospholipids ET-18-OCH 3 (Edelfosine), a proapoptotic agent in tumor cells. Curr Drug Metab 3: 491-525, 2002.

35. Fukuda M: Possible roles of tumor-associated carbohydrate antigens. Cancer Res 56: 2237-2244, 1996.

36. De Ridder L, Mareel M and Vakaet L: Adhesion of malignant and nonmalignant cells to cultured embryonic substrates. Cancer Res 35: 3164-3171, 1975.

37. Deman JJ and Bruyneel EA: Intercellular adhesiveness and neuraminidase effect following release from density inhibition of cell growth. Biochem Biophys Res Commun 17: 895-890, 1975.

38. Deman JJ and Bruyneel EA: Evidence for long-range electrostatic repulsion between HeLa cells. Exp Cell Res 89: 206-216, 1974.

39. Deman JJ, Vakaet LC and Bruyneel EA: Cell size and mutual cell adhesion. II. Evidence for a relation between cell size, longrange electrostatic repulsion and intercellular adhesiveness during density-regulated growth in suspension. J Membr Biol 26: 205-215, 1976. 